\title{
Statistical Analysis of the Relationship between Changes in Plant Phenology and Daily Mean Air Temperature in Japan under Climate Change
}

\author{
Akira NASU*, Yo SHIMIZU* and Kenji OMASA* \\ "Department of Biological and Environmental Engineering, Graduate School of Agricultural and Life Sciences, \\ The University of Tokyo, Tokyo, 113-8657 Japan
}

\begin{abstract}
This study was conducted to verify the relationship between the shifts in plant phenology and changes in air temperature over a 40-year (1961-2001) period in Japan. Daily mean air temperature and annual phenological data (1961-2001) from 101 meteorological stations of the Japan Meteorological Agency were used in this study. The phenological data consists of both springtime phases such as flowering and full flowering, autumn phases such as leaf coloring and leaf fall of trees.

We considered influences of daily temperature being just closed to the date of phenological events, therefore the anomalies of daily mean air temperature between 1961 and 2001 were used. The length of periods during which air temperature affects phenological events was determined by maximization of the correlation coefficients between the cumulated anomalies prior to the date of each phenological event and to the data of each phenological event from 1961 to 2001 by the linear regression.

From the 16 types of plant phenology, the largest was 0.88 for Prunus yedoensis Matsum. flowering. The length of periods with maximum correlation coefficient differed from plant phenology. Results of the analysis suggest that some phenological trends reflected responses to climate change in Japan.

Key words: Climate change, Daily mean air temperature, Japan, Plant phenology, Statistical analysis
\end{abstract}

\section{Introduction}

Plant phenology, which is the timing of various seasonal phenomena of plants, e.g., the flowering, unfolding of leaves, leaf color changes, and leaf fall, has been influenced by changes in environmental factors over the past 50 years (Menzel, 2000; Menzel et al., 2001; Walther et al., 2002). In particular, air temperature is considered the most important determinant of phenology (Masuda et al., 1999). Considering the sensitivity of plant phenology to air temperature, it is an important indicator of potential changes in the ecology of species in response to global warming.

A number of studies in Japan have focused on linear regression analyses between shifts in the plant phenology and changes in air temperature. For example, Masuda et al. (1999) used 12 phenological phases of plants and monthly mean air temperatures. Matsumoto et al. (2003) also used the phenological data for Ginkgo biloba L. and daily mean air temperature, and estimated periods during which air temperature affects phenological events. This study analysed the statistical relationships between 16 types of plant phenological phases and daily mean air temperature from 1961 to 2001 in Japan. The anomaly of daily mean air temperature from 1961 to 2001 was used as the temperature conditions.

\section{Materials and Methods}

This study used the dates of 16 types of plant phenological events (day of year, DOY) and the daily mean air temperature from 1961 to 2001 respectively. Table 1 shows the list of the 16 phenological phases. Data from the 101 meteorological stations of the Japan Meteorological Agency (refer to Fig. 1), which contained a minimum of 10 years of continuous measurements of both phenology and air temperature data were used.

The periods during which air temperature affected phenological events was estimated by linear regression analysis (Matsumoto et al., 2003). In the study of Matsumoto et al., the average date of phenological

Table 1. List of 16 types of phenological events.

\begin{tabular}{|l|l|}
\hline Phenological phase & Species \\
\hline \hline Flowering & $\begin{array}{l}\text { Prunus mume, Camellia japonica, Taraxacum wiggers, } \\
\text { Prunus yedoensis Matsum., Rhododendron kaemp feri, } \\
\text { Wisteria floribunda, Lespedeza bicolor Turcz., } \\
\text { Hydrangea macrophylla Seringe, Lagerstroemia indica, } \\
\text { Miscanthus sinensis }\end{array}$ \\
\hline Full flowering & Prunus yedoensis Matsum. \\
\hline Leaf unfolding & Ginkgo biloba L. \\
\hline Leaf colouring & Ginkgo biloba L., Acer palmatum Thunb. \\
\hline Leaf fall & Ginkgo blloba L., Acer palmatum Thunb. \\
\hline
\end{tabular}




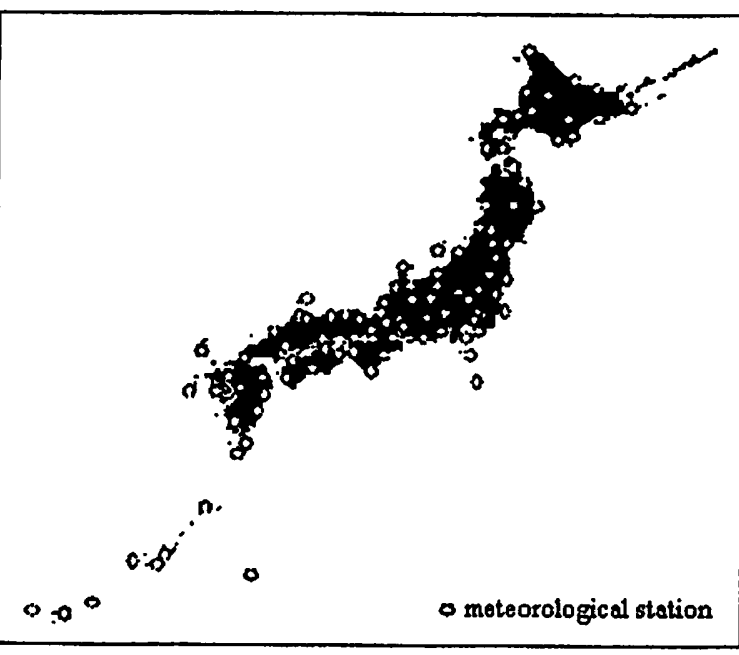

Fig. 1. Locations of meteorological stations at which phenological data were observed.

event from 1953 to 2000 was used as the end date of the period to calculate mean air temperature. Because we considered influences of daily temperature being just closed to the date of phenological events, the anomalies of daily mean air temperature between 1961 and 2001 (from 1 to 150 days prior to the date of the phenological event) were used. We calculated the correlation coefficient of the date of each plant phenological event (DOY) and the cumulated anomalies from 1 to 150 days prior to the date of each phenological event by the linear regression. It was assumed that the length of periods during which air temperature affects phenological events was determined by the period showing the maximum correlation coefficient. We considered 16 phenological phases and temperature conditions in the analysis.

\section{Results and Discussion}

Table 2 shows the results of the linear regression analysis. The length of the periods and correlation coefficients were averaged by the number of meteorological stations which have the results with significance level of $<1 \%$ (F-test). The phenological events of Prunus mume (flowering), Prumus yedoensis

Table 2. The results of the linear regression analysis with significance level of $<1 \%$.

\begin{tabular}{|c|c|c|c|c|c|c|c|}
\hline 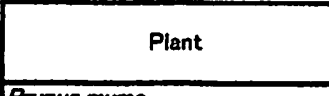 & $\begin{array}{c}\text { Phenological } \\
\text { phase }\end{array}$ & $\begin{array}{c}\text { The number of } \\
\text { tho meteorological } \\
\text { stations }\end{array}$ & Percentago" & $\begin{array}{l}\text { Correlation } \\
\text { coefficient" }\end{array}$ & $\begin{array}{l}\text { Length of the } \\
\text { periods }\end{array}$ & $\begin{array}{l}\text { Percentage of } \\
\text { the positive } \\
\text { trends }\end{array}$ & $\begin{array}{c}\text { Porcentago of } \\
\text { the negative } \\
\text { trends }\end{array}$ \\
\hline $\begin{array}{l}\text { Prenus mume } \\
\text { Camellia japonica } \\
\text { Taraxacum wigsers } \\
\text { Pronus yedoensis Matsum. } \\
\text { Prunus yedoensis Matsum. } \\
\text { Phododondron kaompferi } \\
\text { Wisteria fionibunda } \\
\text { Lespodoza bicolor Turcz. } \\
\text { Hydrangea macrophylla Seringe } \\
\text { Lagerstroemia indica } \\
\text { Miscanthus sinensis } \\
\text { Ginkgo biloba L. } \\
\text { Ginkgo bitoba L. } \\
\text { Ginkgo biloba L. } \\
\text { Acer palmatum Thunb. } \\
\text { Acer palmatum Thunb. }\end{array}$ & $\begin{array}{l}\text { Flowering } \\
\text { Flowering } \\
\text { Flowering } \\
\text { Flowering } \\
\text { Full flowering } \\
\text { Flowering } \\
\text { Flowering } \\
\text { Flowering } \\
\text { Flowering } \\
\text { Flowering } \\
\text { Flowering } \\
\text { Leaf unfolding } \\
\text { Leaf colouring } \\
\text { Leaf fall } \\
\text { Leaf colouring } \\
\text { Leaf fall } \\
\end{array}$ & $\begin{array}{l}83 \\
78 \\
88 \\
99 \\
99 \\
80 \\
74 \\
73 \\
88 \\
74 \\
83 \\
76 \\
74 \\
76 \\
76 \\
77\end{array}$ & $\begin{array}{r}92 \\
77 \\
83 \\
93 \\
93 \\
70 \\
100 \\
32 \\
73 \\
65 \\
24 \\
95 \\
78 \\
76 \\
87 \\
71 \\
\end{array}$ & $\begin{array}{l}0.75 \\
0.62 \\
0.63 \\
0.88 \\
0.85 \\
0.70 \\
0.71 \\
0.53 \\
0.75 \\
0.59 \\
0.51 \\
0.70 \\
0.62 \\
0.61 \\
0.62 \\
0.59 \\
\end{array}$ & $\begin{array}{r}59 \\
70 \\
62 \\
46 \\
46 \\
65 \\
54 \\
99 \\
108 \\
80 \\
76 \\
44 \\
58 \\
78 \\
60 \\
82\end{array}$ & $\begin{array}{r}1 \\
5 \\
0 \\
0 \\
1 \\
0 \\
0 \\
35 \\
0 \\
0 \\
85 \\
0 \\
100 \\
100 \\
100 \\
100\end{array}$ & $\begin{array}{r}99 \\
95 \\
100 \\
100 \\
99 \\
100 \\
100 \\
65 \\
100 \\
100 \\
15 \\
100 \\
0 \\
0 \\
0 \\
0\end{array}$ \\
\hline
\end{tabular}

* : Percentage of the metcorological stations with significance lovel of $<1 \%$

** : Average value of the stations with significance level of $\langle 1 \%$

* Porcentage on the basis of the stations with significance lovel of $<1 \%$

Table 3. Results comparison of the linear regression analysis on the leaf unfolding and leaf fall of Ginkgo biloba L. between the study of Matsumoto et al., (2003) and this study.

\begin{tabular}{|c|c|c|c|c|c|c|c|}
\hline & Plant & $\begin{array}{c}\text { Phenological } \\
\text { phase }\end{array}$ & $\begin{array}{c}\text { The number of } \\
\text { the metcorological } \\
\text { stations }\end{array}$ & Percentage" & $\begin{array}{l}\text { Correlation } \\
\text { coefficient }\end{array}$ & $\begin{array}{l}\text { Percentage of } \\
\text { the positive } \\
\text { trends }\end{array}$ & $\begin{array}{c}\text { Percentage of } \\
\text { the negative } \\
\text { trends }\end{array}$ \\
\hline \multirow{2}{*}{ This study } & \multirow{2}{*}{ Ginkgo biloba L. } & Leaf unfolding & 70 & 94 & 0.69 & 0 & 100 \\
\hline & & Leaf fall & 68 & 80 & 0.61 & 100 & 0 \\
\hline \multirow{2}{*}{$\begin{array}{l}\text { Matsumoto } \\
\text { et al.,(2003) }\end{array}$} & \multirow{2}{*}{ Ginkgo biloba L. } & Leaf unfolding & 65 & 83 & no data & 0 & 100 \\
\hline & & Leaf fall & 64 & 70 & no data & 100 & 0 \\
\hline
\end{tabular}

* : Percentage of the meteorological stations with significance lovel of $<1 \%$

** : Average value of the stations with significance level of $\langle 1 \%$

***: Percentage on the basis of the stations with significanco level of $<1 \%$ 
Matsum. (flowering and full flowering), Wisteria floribunda (flowering) and Ginkgo biloba L. (leaf unfolding) showed high percentages and high correlation coefficients. Therefore, the sensitivities of these phenological events to air temperature are relatively high over Japan.

The length of the periods with maximum correlation coefficient differed from plant phenophases. The shortest average length of the periods in the 16 types of plant phenology was 44 days in the case of leaf unfolding of Ginkgo biloba L. The longest was 106 days for Hydrangea macrophylla Seringe flowering. In most of the meteorological stations, the slopes of the regression line on plant phenology in spring had negative values. On the other hand, the plant phenology in autumn had positive values. For a negative trend (a negative relationship), the dates of phenological events implied an advanced according to the increase in temperature, while, positive relationships meant that the date of phenological events are delayed.

We compared the results of this study with that of Matsumoto et al. (2003) about the leaf unfolding and leaf fall of Ginkgo biloba L. (Table 3). The meteorological stations used for the statistical analysis were the 70 meteorological stations with more than 25 years of records for both phenological and air temperature data. The meteorological stations that satisfied significance level of $<1 \%$ (F-test) was $94 \%$ in the case of leaf unfolding of Ginkgo biloba $\mathrm{L}$. and $80 \%$ in the case of leaf fall. Similarly, Matsumoto et al., (2003) also obtained high percentage with 83 and 70 for 65 and 64 meteorological stations respectively. Therefore, we found that the results of two methods were similar.
In conclusion, using the anomaly of daily temperature data, we analysed the relationships between 16 types of plant phenological events and temperature conditions. Results of the analysis suggest that some phenological trends reflected responses to climate change in Japan.

\section{References}

Matsumoto, K., Ohta, T., Irasawa, M. and Nakamura, T., 2003: Climate change and extension of the Ginkgo biloba L. growing season in Japan. Glob. Change. Biol., 9, 1634-1642.

Masuda, K., Yoshino, M. and Park, H., 1999: The impact and detection of global warming phenomenon by phenology. Global. Environ. Res., 4(1\&2), 91-103.

Menzel, A., 2000: Trends in phenological phases in Europe between 1951 and 1996. Int. J. Biometeorol., 44, 76-81.

Menzel, A., Estrella, N. and Fabian, P., 2001: Spatial and temporal variability of the phenological seasons in Germany from 1951 to 1996. Glob. Change. Biol., 7, 657-666.

Walther, GR., Post, E., Convey, P., Menzel, A., Parmesan, C., Beebee, TJC., Fromentin, JM., Hoegh-Guldberg, O. and Bairlein, F., 2002: Ecological responses to recent climate change. Nature., 416, 389-395. 